\title{
A Truly Liquid Investment
}

\section{INVESTMENT OPPORTUNITIES FLOW FROM WATER INITIATIVES}

By Sherree DeCovny

Large parts of the world are running short on water-even experiencing "desertification" —at an alarming rate. Innovative solutions being implemented by the public and the private sectors may offer interesting opportunities for investors.

Several factors are driving water shortages. Climate change could have the greatest global impact. Some projections have temperatures around the globe warming by three to four degrees (Fahrenheit) over the next century, which

Environmental changes, population growth, contamination, and aging infrastructure are all contributing to water shortages.

Solving such problems will require input from the for-profit and not-for-profit sectors.

By targeting water initiatives, investors may find secular growth in municipal bonds, public and private company shareholdings, and exchange-traded funds. would affect water in many ways. Some areas would stay the same, but many others would be either flooded or stricken with drought.

Population growth is also putting pressure on clean surface freshwater resources in lakes and rivers. Brackish water must be treated before it is used for human consumption, and groundwater is harder to use because it must be pumped.

According to Julie Gorte, senior vice president for sustainable investing at PAX World Management, 96.5\% of all the water on Earth is brackish and $1 \%$ is saline. Only the remaining $2.5 \%$ is fresh, and of that, $1.2 \%(0.03 \%$ of all water) is surface fresh water. Of the surface fresh water, $30 \%$ is groundwater, and $69 \%$ is currently locked up in glaciers and icecaps.

The more fresh surface water is used, the more it becomes contaminated. Industrial use is a major issue. For example, hydraulic fracturing, or "fracking," takes about 5 million gallons of water to frack a well once. The water becomes highly contaminated, and treating it is extremely expensive.

Some countries with large populations are experiencing drought conditions, yet much of their water is contaminated. About $60 \%$ of China's groundwater-which makes up about one-third of the country's water resources-was rated unfit for human consumption by China's Ministry of Land and Resources. In India, 80\% of sewage flows into rivers without being treated, according to a 2013 study by the Centre for Science and Environment.

Accessing water in underground aquifers is also a challenge. Boreholes can be neglected for years or can be vandalized (sometimes as a result of war). In such cases, wells need to be rehabilitated. In other cases, springs are unprotected, which allows the water to become contaminated. Many communities lack the financial resources to hire engineers and well drillers with the expertise to access and protect the water. Where water is accessible, commercial applications, such as farming, often deplete the supply.

Finally, the availability of ongoing service and support for communities that have previously benefited from safewater projects is an important consideration.

"For every community that receives first-time access, another community somewhere else is losing the access they once had because of lack of maintenance or continued investment in their water system," says Stan Patyrak, vice president of strategy and development at The Water Project.

\section{INNOVATIVE SOLUTIONS}

In developing countries, not-for-profit organizations, such as The Water Project, collaborate with local organizations to help improve their capacity to provide sustainable water and sanitation projects. The Water Project's programs in sub-Saharan Africa focus on water delivery and service, community engagement, hygiene, sanitation training, and ongoing monitoring. Programs sometimes use outside (private sector) hydrogeologists, engineers, and consultants. Moreover, local businesses supply spare parts and provide ongoing maintenance.

Drilling and repairing wells, building dams, protecting springs, and harvesting rain are often the easy part. The main challenge is keeping water flowing. People from the community, local and national governments, and the private sector all have a role to play.

In developed countries, public authorities are addressing the problem through cultural change and technological innovation. Consider the example of Las Vegas. Of 280 major US cities, Las Vegas ranks at the bottom of the list in terms of rainfall, which may explain why it is one of the most water-efficient cities on Earth. Its public authority has taken steps to protect the availability of fresh water by regulating where grass can be put on golf courses, for instance, and what kind of water can be used in fountains.

In the US, California is a case study for drought. In some municipalities, especially near coastlines, salt water is intruding into the groundwater. If too much fresh water is being taken out of the groundwater, sea water will seep in and make the groundwater brackish or saline. It then cannot be used for agriculture, drinking, or hygiene without treatment.

One potential solution frequently used in the Middle East is desalination; the problem with this process, however, is that it is not environmentally friendly. Desalination 
plants suck water from the ocean, put the contents through a reverse osmosis process, and then dump the briny waste back into the ocean.

Desalination is also energy intensive and reliant on fossil fuels, although companies are starting to use solar energy and wind to power the plants. In California, WaterFX will soon open the first commercial solar-powered desalination plant. The modular technology is located right where it is needed, in this case in the Central Valley-the heart of the state's agriculture. Rather than processing ocean water and then transporting it inland, the company recycles unusable, salty drainage water from irrigation into potable water for use by local water districts.

\section{THE MASSIVE AMOUNT OF INVESTMENT REQUIRED PROVIDES AN OPPORTUNITY TO INVEST IN MUNICIPAL SECURITIES OVER THE NEXT 20 TO 30 YEARS. FOUR OF THE TOP FIVE ISSUERS OFFER DOMESTIC INVESTORS A DOUBLE TAX- EXEMPT STATUS ON RETURNS, AND THE ISSUERS HAVE HIGH CREDIT RATINGS.}

"Amazingly, this process changes farmers from being huge water consumers into water producers. They can actually get paid for their water," says Rona Fried, CEO of SustainableBusiness.com. "And the resulting clean water costs about the same as what farmers pay today, much less than water desalinated from the ocean."

Other methods are being used to minimize the amount of water used in agriculture. Drip irrigation alone can reduce water usage by $20 \%$. Software and sensors allow farmers to track moisture levels in the soil (minimizing irrigation), and drones are beginning to be used to monitor soil conditions from above. Farmers will likely switch to crops that match their local water conditions.

California is turning to other innovative solutions as well. Orange County is implementing artificial groundwater recharge systems, which route surface water back into the groundwater, as well as using treated wastewater for such purposes as drinking and agriculture. Los Angeles recently dropped 96 million "shade balls," which float on water and block sunlight, into a reservoir holding 3.3 billion gallons of water, thereby reducing evaporation and making the water less susceptible to algae, bacterial growth, and chemical reactions.

\section{INVESTMENT OPPORTUNITIES}

As US water and sewer systems deteriorate, an estimated $\$ 1$ trillion in new investments will be needed to rehabilitate water infrastructure over the next 25 years, according to the American Water

Works Association. Further, the American Society of Civil Engineers estimates that the cumulative capital investment gap for US water infrastructure will rise from $\$ 100$ billion in 2015 to nearly $\$ 200$ billion in 2040 .

"The massive amount of investment required provides an opportunity to invest in municipal securities over the next 20 to 30 years," says Zareh Baghdassarian, municipal and corporate credit analyst at NewOak Capital. "Four of the top five issuers-California, New York, Florida, and Pennsylvania-offer domestic investors a double tax-exempt status on returns, and the issuers have high credit ratings."

For example, the Los Angeles Department of Water and Power's municipal bonds ( $5 \mathrm{~s}$ in 2044) yield around 3.5\%, which equates to almost $8 \%$ when the double tax exemption is counted.

Municipalities have contracts with regulated utilities that provide water to residents and treat the water. Water utilities are public companies, so investors may trade in their stocks and bonds. In addition, they can invest in public companieswhich supply the industry with pumps, pipes, filtration and treatment systems, and other technology-as well as waterrelated technology companies, such as biotech firms. It is also possible to make private equity investments in small companies that are innovating in this space. Of course, because smaller companies have different financial characteristics than larger public ones, returns may be more volatile.

Another recent development comes for the exchangetraded fund (ETF) sector. The PowerShares Water Resources Portfolio ETF is based on the NASDAQ OMX US Water Index. The constituents of the index are selected by Rona Fried (CEO of SustainableBusiness.com). She first looks at how much of the company's revenue is driven by water solutions, shooting for a minimum of $50 \%$. Companies that are considered leaders in the industry may also be included, even if water is not their dominant product. She then looks at how a company runs its water business from a sustainability perspective. For example, do wastewater treatment companies use chemicals to treat water, or are they using advanced technologies that treat water biologically? Are they improving the energy efficiency of their plants and incorporating water recycling and/or bio-gas?

As Gorte points out, investors hoping to earn a return need to keep in mind that any company, security, or idea is capable of underperforming depending on economic factors and the financial/business cycle. Some industries are more cyclical than others. Utilities tend to have less cyclical volatility, and technology companies may be more volatile. Ultimately, Gorte believes investors should look for well-managed companies.

KEEP GOING

"Bonds and Climate Change," CFA Institute Conference Proceedings Quarterly (First Quarter 2015) [www.cfapubs.org]

"Using ESG Factors for Equity Valuation," CFA Institute Magazine (November/December 2014) [www.cfapubs.org]
"There's a lot of innovation in how to move water around and treat it and make it available more efficiently with less loss," she concludes. "That's a nice, long-term secular growth prospect."

Sherree DeCovny is a freelance journalist specializing in finance and technology. 